\title{
HIV/AIDS E EFETIVAÇÃO DO DIREITO FUNDAMENTAL À SAÚDE E PREVIDÊNCIA SOCIAL: INCAPACIDADE DE ACORDO COM A SÚMULA 78 DA TURMA NACIONAL DE UNIFORMIZAÇÃO (TNU)
}

\author{
Nathanael Lisboa Teodoro da Silva ${ }^{1}$ \\ Maria Aparecida Alkimim²
}

\begin{abstract}
Resumo
A presente pesquisa analisa a situação jurídica dos portadores do HIV/AIDS e efetivação do direito fundamental à saúde e previdência social em face da dignidade da pessoa humana e as hipóteses em que o portador do HIV poderá obter direito as prestações previdenciárias por incapacidade junto ao Regime Geral da Previdência Social. Serão demonstrados os estágios do vírus, contexto histórico e estigmas sociais, trazendo o conceito de incapacidade da Súmula 78 da TNU. A metodologia aplicada abrange a pesquisa descritiva, documental e bibliográfica.
\end{abstract}

Palavras-chave: HIV/AIDS; Incapacidade; Benefícios previdenciários; Súmula 78 da TNU; Direitos fundamentais.

\section{HIV/AIDS AND THE REALIZATION OF THE FUNDAMENTAL RIGHT TO HEALTH AND SOCIAL SECURITY: INCAPACITY ACCORDING TO PRECEDENT 78 OF THE NATIONAL GROUP OF UNIFORMIZATION (TNU)}

\begin{abstract}
The present study analyzes the legal situation of people living with HIV/AIDS and the realization of the fundamental right to health and social security in the face of the dignity of the human person, and the hypotheses in which the HIV patient can obtain the right to social security benefits due to disability General Social Security System. The stages of the virus, historical context and social stigmas will be demonstrated, bringing the concept of incapacity of the Precedent 78 of the TNU. The applied methodology covers the descriptive, documentary and bibliographic research.

Keywords: HIV/AIDS; Inability; Social security benefits; Summary 78 of the TNU; Fundamental rights.

\footnotetext{
${ }^{1}$ Mestrando em Direitos Sociais, Econômicos e Culturais pelo Centro Universitário Salesiano de São Paulo (UNISAL). Pós-Graduação Lato Sensu em Direito Previdenciário pela Universidade Anhanguera UNIDERP. Membro do Grupo de Pesquisa Direitos Humanos cadastrado junto ao CNPq. Advogado militante nas áreas Previdenciária e Trabalhista. E-mail: nathanaelteodoroadv@ gmail.com.

${ }^{2}$ Doutorado em Direito pela Pontifícia Universidade Católica de São Paulo (2007); Mestrado em Direito pela Pontifícia Universidade Católica de São Paulo (2004); Coordenadora do Programa de Mestrado em Direito do Centro Universitário Salesiano de São Paulo-UE de Lorena; Professora e Pesquisadora do Programa de Mestrado em Direito do Centro Universitário Salesiano de São Paulo, Professora do Curso de Direito do Centro Universitário Salesiano de São Paulo, Professora membro do Conselho Editorial da Revista Direito \& Paz do Centro Universitário Salesiano de São Paulo. Professora integrante do Observatório de Violências nas Escolas, que compõe a Cátedra da UNESCO de Juventude, Educação e Sociedade, com sede na Universidade Católica de Brasília; Participante do Grupo de Pesquisa "Direitos de Titularidade Difusa e Coletiva". Membro do Comitê de Ética em Pesquisa (CEP) do Centro Universitário Salesiano de São Paulo. Pós-doutoramento em Democracia e Direitos Humanos pela Universidade de Coimbra/IUS Gentium Conimbrigae. E-mail: maalkimin @ terra.com.br.
} 


\section{Introdução}

A Síndrome da Imunodeficiência Adquirida (AIDS) é uma doença viral identificada em 1981, e caracteriza-se por diversas manifestações clínicas provocadas pela presença do Vírus da Imunodeficiência Humana (HIV).

Tal vírus foi responsável pelo óbito de diversas pessoas ao redor do mundo, bem como no Brasil, e constitui até os dias atuais causa de discriminação, segregação e desigualdade social. Pretende-se demonstrar que o direito dos portadores do HIV/AIDS à saúde e previdência é um direito fundamental na ordem jurídico-constitucional, e merece ser estudo e concretizado, vez que os comportamentos discriminatórios além de ferir a dignidade da pessoa humana resultam na incapacidade para o trabalho dos portadores do vírus HIV/AIDS.

A incapacidade para o trabalho dos portadores do vírus gera direito ao recebimento dos benefícios previdenciários por incapacidade (auxílio-doença e aposentadoria por invalidez). Tais prestações devem ser requeridas inicialmente junto ao Instituto Nacional do Seguro Social (INSS), autarquia federal responsável pela administração do plano de benefícios e serviços.

Contudo, a autarquia previdenciária ao examinar as condições patológicas deixa de observar os problemas que cercam o portador do vírus HIV, tais como o estigma, preconceito, reações ao tratamento etc., empregando análise restrita quanto ao caso.

Assim, o presente trabalho busca através de pesquisa documental e bibliográfica, em especial livros, artigos, legislação e jurisprudência demonstrar de acordo com a súmula $\mathrm{n}^{\mathrm{o}} 78$ da Turma Nacional de Uniformização (TNU) dos Juizados Especiais Federais que as condições pessoais, sociais, econômicas e culturais podem ser ponderadas no caso concreto de forma a analisar a incapacidade em sentido amplo do portador do HIV/AIDS.

\section{Breve relato sobre o HIV e a AIDS}

Analisando-se o contexto histórico extrai-se que a AIDS é uma doença viral, infecciosa e fatal. Segundo José Rodrigues Coura (2008) a AIDS foi identificada pela primeira vez nos Estados Unidos da América (EUA) em julho de 1981. Tal patologia caracteriza-se por diversas manifestações clínicas provocadas pela presença do HIV. 
O vírus da imunodeficiência humana (HIV) destrói os mecanismos de defesa naturais do corpo humano e permite que as mais variadas doenças nele se instalem, constituindo- se síndrome da imunodeficiência adquirida (aids). Ao longo dos anos, a infecção pelo HIV tem apresentado diversas transformações, tanto no que se refere à evolução clínica quanto ao perfil epidemiológico das pessoas infectadas. (AFFELDT; SILVEIRA; BARCELOS, 2015, p.80)

Segundo o Ministério da Saúde (2010) o HIV pode ser transmitido pela via sexual, pelo sangue e pelo leite materno.

Vale relatar que desde a introdução do vírus no organismo o ser humano atravessa diferentes estágios clínicos e laboratoriais, quais sejam:

a) Portador assintomático ou soropositivo: é a pessoa que, tendo tido contado com o vírus e possuindo anticorpos detectáveis em seu sangue, não apresenta sintomas, podendo vir a desenvolver a doença ou não.

b) Doente com Complexo Relacionado à AIDS (ARC) é a etapa em que a pessoa, já sendo soropositivo, apresenta sintomas e sinais inespecíficos de intensidade variável, além de processos de menor gravidade, podendo exteriorizar fadiga, diarreia crônicas, emagrecimento, febre etc.

c) Doente com AIDS: é aquela pessoa em que a imunodepressão provocada pelo HIV atinge um grau mais acentuado, resultando tumores, infecções, entre outros.

Assim, nota-se que quando a pessoa se infecta pelo HIV o sistema imunitário vai reagir produzindo anticorpos contra o HIV, contudo, com o tempo o vírus se multiplica, surgindo assim os sintomas da infecção.

Pode-se afirmar que a fase da AIDS é um período avançado do estágio com sintomas, isto é, quando o sujeito infectado pelo HIV passa a ter infecções resultantes da deficiência do sistema imunitário.

Dentre os inúmeros casos que resultam na AIDS pela transmissão do vírus do HIV estão o relacionamento sexual, dependentes tóxicos que fazem uso da via endovenosa e transfusão sanguínea.

Conforme o ensinamento de Antonio Carlos de Castro Toledo Junior (2006, p. 93) a “aids envolve questões sociais, pessoais e emocionais complexas". No início da década de 1980 quando se iniciou os estudos detectou-se a presença maciça do vírus em homossexuais e prostitutas, gerando assim na sociedade de modo geral comportamento discriminatório. 
Atualmente o número de casos de HIV no sexo masculino é maior entre heterossexuais, porém, a epidemia no país ainda é concentrada em grupos populacionais com comportamentos que os expõem a um risco maior de infecção pelo HIV, como homossexuais, prostitutas e usuários de drogas.

De 1981 até o ano de 2016 a Organização Mundial da Saúde (OMS) estima que 36 milhões de pessoas morreram pelo HIV ao redor do mundo. Segundo o programa de coordenação da Organização das Nações Unidas (ONU) contra a aids 36,7 milhões de pessoas vivem atualmente no mundo com o HIV.

No Brasil segundo o Departamento de Vigilância, Prevenção e Controle das Infecções Sexualmente Transmissíveis (IST), do HIV/AIDS e das Hepatites Virais, existem 656.701 casos registrados de AIDS (condição em que a doença já se manifestou), de acordo com o último Boletim Epidemiológico. Em 2011 foram notificados 38.776 casos da doença e a taxa de incidência de AIDS no Brasil foi de 20,2 casos por 100 mil habitantes.

Na década de 1990 a Terapia antirretroviral tripla de alta potencia (TARV), conhecido como "coquetel", e inaugurada pelo governo brasileiro em 1996 deu causa a redução na mortalidade, diminuição na frequência e duração de internações, bem como contribuindo para o aumento da sobrevida (ALENCAR, 2008; NEMES, 2008; VELLOSO, 2008).

A AIDS se cerca de questões complexas, com repercussão nas relações sociais e inclusive na relação previdenciária.

\section{HIV/AIDS e os direitos fundamentais: direito à saúde e à igualdade e não- discriminação}

Os direitos fundamentais, conhecidos também como direitos naturais, direitos humanos, entre outros termos, se referem aos direitos do homem positivados em determinada Carta, tendo como pilar a dignidade humana.

Assim, passa-se a analisar os direitos fundamentais do portador do HIV/AIDS, especialmente direito à saúde, igualdade e não discriminação.

\subsection{Direitos Humanos e dignidade pessoa humana}


Prevista no art. $1^{\circ}$, inc. III, da Constituição Federal a dignidade da pessoa humana se revela como um dos Fundamentos do Estado Democrático (e Social) de Direito, pois é o Estado que existe em função da pessoa humana (SARLET, 2002, p. 68).

A dignidade da pessoa humana para SARLET (, 2002, p. 74) constitui "valor-guia não apenas dos direitos fundamentais mas de toda a ordem jurídica (constitucional e infraconstitucional)".

Da dignidade decorre o respeito, o bom trato e a igualdade nas relações sociais, em especial no relacionamento da sociedade com os portadores do HIV/AIDS, pois o "estigma e a discriminação estão entre as principais obstáculos para a prevenção, tratamento, cuidado em relação ao HIV" (UNAIDS, 2017).

Assim, a dignidade da pessoa humana é um princípio, um valor que deve ser observado de modo que os portadores do HIV possam obter acesso a tratamentos adequados, respeitando e sendo respeitado, exercendo com liberdade os direitos civis e políticos de forma plena.

\subsection{Direitos fundamentais do portador do HIV/AIDS}

Os direitos fundamentais podem ser definidos como os direitos e garantias do homem que se encontram positivados em uma Constituição. Às vezes as expressões Direitos Humanos e Direitos Fundamentais são utilizadas com o mesmo sentido e significado. Segundo SARLET (2015, p. 27) também afirma que outras expressões são largamente utilizadas para se referir a direitos fundamentais tais como: "direitos humanos", "direitos do homem”, “direitos subjetivos públicos”, “ liberdades públicas”, etc.

De acordo com Norberto Bobbio (2004, p.5) os "direitos do homem, por mais fundamentais que sejam, são direitos históricos, ou seja, nascidos em certas circunstâncias, caracterizadas por lutas em defesa de novas liberdades contra velhos poderes, e nascidos de modo gradual, não todos de uma vez e nem de uma vez por todas".

$\mathrm{O}$ direito fundamental à saúde destina-se a assegurar às pessoas e à coletividade condições de bem-estar físico, mental e social. 


\subsubsection{Direito fundamental à saúde à luz da segunda dimensão dos direitos fundamentais}

O direito fundamental à saúde se encontra previsto no art. 196 da Constituição Federal. Tal prestação é direito de todos e dever do Estado, ou seja, o acesso ao serviço de saúde não depende de contribuição e deve ser implementado e garantido mediante políticas sociais e econômicas que visem à redução do risco de doença e de outros agravos e ao acesso universal e igualitário às ações e serviços para sua promoção, proteção e recuperação.

Em conjunto com a previdência social e assistência social a saúde é classificada como direito social pela Carta Magna, sendo usualmente enquadrado como direito de segunda dimensão ou geração (IBRAHIM, 2009, p. 4) pois descendente de luta contra as desigualdades sociais que resultaram na formação do denominado estado de bem-estar social ou Welfare state materializado segundo $\operatorname{Ibrahim~}(2009$, p. 6) "pela legislação social, traz a ideia de cooperação, ação concreta do ideal de solidariedade, superando-se o individualismo clássico do estado liberal”.

O direito à saúde é um direito fundamental pois decorre de necessidades "que são iguais para todos os seres humanos e que devem ser atendidas para que a pessoa possa viver com dignidade que deve ser assegurada a todas as pessoas" (SERRANO, 2017, p. 179).

A Lei 8.080/90 que dispõe sobre as condições para a promoção, proteção e recuperação da saúde, a organização e o funcionamento dos serviços correspondentes e dá outras providências diz no art. $2^{\circ}$ que "a saúde é um direito fundamental do ser humano, devendo o Estado prover as condições indispensáveis ao seu pleno exercício" (BRASIL, 1990).

Segundo o Portal Saúde (BRASIL, 2014) em 1989, profissionais da saúde e membros da sociedade civil criaram, com o apoio do Departamento de Doenças Sexualmente Transmissíveis (DST), Aids e Hepatites Virais, a Declaração dos Direitos Fundamentais da Pessoa Portadora do Vírus da Aids. Tal Declaração é decorrente de um direito fundamental, sendo que os portadores do HIV/AIDS têm:

a) Direito à informação clara, exata, sobre a aids;

b) Direito a informações específicas sobre sua condição;

c) Direito à assistência e ao tratamento, dados sem qualquer restrição, garantindo sua melhor qualidade de vida. 
No Brasil o atendimento aos portadores do HIV/AIDS é garantido pelo Sistema Único de Saúde (SUS) sendo que tal sistema é financiado com recursos do orçamento da seguridade social, da União, dos Estados, do Distrito Federal e dos Municípios, além de outras fontes. (IBRAHIM, 2009, p. 9).

Importante frisar que o direito fundamental à saúde não se resume aos tratamentos medicamentosos, cirúrgicos e terapêuticos. Segundo o art. 3ำ da Lei 8.080 (BRASIL, 1990) os níveis de saúde expressam a organização social e econômica do País, tendo a saúde como determinantes e condicionantes, entre outros, a alimentação, a moradia, o saneamento básico, o meio ambiente, o trabalho, a renda, a educação, a atividade física, o transporte, o lazer e o acesso aos bens e serviços essenciais.

$\mathrm{O}$ direito fundamental à saúde destina-se a assegurar às pessoas e à coletividade condições de bem-estar físico, mental e social.

\subsubsection{Direito fundamental à igualdade e não-discriminação do portador do HIV/AIDS}

Constata-se que em pleno século XXI e com todo avanço científico e intelectual ainda subsiste na sociedade a discriminação, segregação e desigualdade social em diferentes formas. Entre as vítimas da discriminação e desigualdade que abala as estruturas sociais estão os portadores do HIV/AIDS.

Contudo, o ordenamento jurídico internacional e pátrio asseguram e objetivam a todos a igualdade e não discriminação.

O caput do art. $5^{\circ}$ da Constituição Federal diz que "todos são iguais perante a lei, sem distinção de qualquer natureza...” (BRASIL, 1988), porém deve-se distinguir a igualdade forma da igualdade material. Segundo Sergio Pinto Martins (2007, p. 46) a igualdade formal é igualdade perante a lei, e a igualdade material é a que tem por fim proporcionar tratamento igual aos iguais e desigual aos desiguais.

Qualquer direito que venha a favorecer e proporcionar ao portador do HIV/AIDS um "privilégio" na esfera da seguridade social encontrará seu respaldo na Carta Maior, Cartas Internacionais e legislação infraconstitucional, seja através de tratamentos, políticas públicas, prestações previdenciária etc. pois estará colocando no mesmo nível os portadores do vírus e os demais cidadãos. 
A não discriminação entendida por José Afonso da Silva (2016, p. 96) como princípio relativo à prestação positiva do Estado se encontra no art. $3^{\circ}$, IV da Constituição Federal e constitui um dos objetivos fundamentais da Republica Federativa do Brasil.

Tratamentos, políticas públicas, prestações previdenciária etc. reveladas através de prestações positivas do Estado e a não discriminação constituem Direitos Fundamentais da Pessoa Portadora do HIV/AIDS, de modo que todo portador do HIV/AIDS venha a participar em todos os aspectos da vida social, em especial à continuação de sua vida civil, profissional, sexual e afetiva, sem nenhuma restrição à cidadania (BRASIL, 2014).

\section{AIDS/HIV e a incapacidade para o trabalho conforme a súmula 78 da TNU}

Conforme o item 4.1 do Manual de Perícia Médica da Previdência Social, a “incapacidade laborativa é a impossibilidade de desempenho das funções específicas de uma atividade ou ocupação, em consequência de alterações morfopsicofisiológicas provocadas por doença ou acidente"(BRASIL, 2017).

De acordo com Frederico Amado (2014, p. 521) a incapacidade laborativa pode ser classificada quanto ao grau como total ou parcial e quanto à duração como temporária (prazo previsível para a duração) ou de duração indefinida (prazo imprevisível).

Conforme a profissão a incapacidade para o trabalho pode ser classificada como:

\footnotetext{
a) uniprofissional - aquela em que o impedimento alcança apenas uma atividade específica;

b) multiprofissional - aquela em que o impedimento abrange diversas atividades profissionais;

c) omniprofissional - aquela que implica a impossibilidade do desempenho de toda e qualquer atividade laborativa, sendo conceito essencialmente teórico, salvo quando em caráter transitório. (AMADO, 2014, p. 522)
}

A definição de incapacidade total e permanente se encontra no art. 42 da Lei 8.213/91 e art. 43 do Decreto 3.048/99 significando a incapacidade que resulta na insustetibilidade de reabilitação do segurado para as atividades de trabalho.

Incapacidade parcial segundo AMADO (2014, p. 521) "é aquela que prejudica o desenvolvimento de algumas atividades habituais do segurado, mas não de todas, sem risco de vida ou agravamento maior". 
O direito aos benefícios previdenciários em razão da incapacidade deve ser analisado num primeiro plano pelos profissionais da área de saúde, em específico pelos médicos especialistas que vão relatar o real estado do doente após a realização dos exames e consultas.

Tais profissionais vão auxiliar e influenciar nas decisões do próprio paciente, do Instituto Nacional do Seguro Social (INSS), do empregador e do Poder Judiciário quando provocado, vez que trata-se de ato que somente determinada pessoa qualificada poderá atestar ou não a presença de determinada patologia incapacitante.

Entretanto, o INSS ao valorar a incapacidade observa somente as doenças típicas, através dos médicos-peritos. Segundo IBRAHIM (2009, p. 647) "a previdência social ainda reluta em admitir a existência de incapacidades de outra ordem, de natureza moral ou social, quando não há inaptidão funcional, fisiológica do segurado, mas de outra ordem”.

Assim, no que tange a valoração e classificação da incapacidade entende-se que tantos os médicos como os julgadores poderiam efetuar tal ato, valendo-se de uma análise mais abrangente e não restritiva de modo a estabelecer não somente a incapacidade funcional/fisiológica como também a incapacidade social, sendo que a incapacidade social é resultante de diversos fatores que envolvem o segurado.

A incapacidade social pode ser verificada nos casos de portadores do HIV/AIDS. Sabe-se que a AIDS não é uma doença que atinge somente a parte física propriamente dita do ser humano, tal patologia pode gerar implicações psicológicas ao enfermo, aos seus familiares, sentimento de raiva dirigido ao doente, sentimento de culpa, vergonha, medo da morte, depressão etc.

A incapacidade laboral numa primeira análise pode ser demonstrada e visualizada de forma objetiva, vez que as reações de febre, dor, mal estar, enjoo etc., se manifestam em quase todas as pessoas portadoras da patologia e geram diminuição ou supressão da força laboral.

Nos ano 1980, a AIDS era descrita como condição aguda, uma vez que manifestava rapidamente depois do diagnóstico, não havia tratamentos disponíveis e seu desfecho era rápido, com altas taxas de mortalidade. Com o surgimento da terapia antirretroviral tripla de alta potencia (TARV), conhecida como “coquetel” ocorreu à redução da mortalidade, diminuição na frequência e duração de internações, bem como o aumento da sobrevida. 
Todavia, mesmo com os "coquetéis" efeitos colaterais podem surgir como a síndrome lipodistrófica do HIV que é:

\footnotetext{
Um distúrbio na distribuição na distribuição de gordura corporal, com acúmulos de gordura que podem aparecer na região abdominal, na parte posterior do pescoço e na região peitoral, perda de gordura na face, braços, pernas e nádegas (ALENCAR, 2008; NEMES, 2008; VELLOSO, 2008, p. 1843)
}

As manifestações da doença podem trazer sérios problemas no local de trabalho para o detentor do infortúnio supramencionado, gerando uma sensível diminuição na capacidade laborativa do segurado empregado, contribuinte individual, trabalhador doméstico e segurado especial.

O HIV/AIDS como já mencionado pode gerar problemas psíquicos tais como depressão, ansiedades, transtornos etc. conferindo aos portadores do vírus uma carga expressiva de preconceito e estigma. O Decreto 3048/99 (Regulamento da Previdência Social) inclusive traz no anexo II, listas A e B a doença pelo HIV como patologia profissional ou relacionada ao trabalho.

$\mathrm{Na}$ Lista A que se refere a agentes ou fatores de risco de natureza ocupacional relacionados com a etiologia de doenças profissionais e de outras doenças relacionados com o trabalho, consta no item XXV.10 o HIV como microorganismo e parasitas infecciosos expõem o trabalhador a risco. Também, na lista $\mathrm{B}$, que se refere às doenças infecciosas $\mathrm{e}$ parasitárias relacionadas com o Trabalho, o HIV está mencionado no item X.

Em razão do preconceito e estigma, o convívio do portador do HIV com outras pessoas pode passar a ser vetor de agravamento da doença, resultando na falta de aptidão momentânea ou prolongada para o exercício da atividade profissional, pois existe de forma nítida uma segregação aos portadores do vírus na sociedade.

Assim, para se avaliar à incapacidade para o trabalho do portador do HIV/AIDS a Turma Nacional de Uniformização de Jurisprudência (TNU) dos Juizados Especiais Federais aprovou o enunciado $\mathrm{n}^{\mathrm{o}} 78$ nos seguintes termos: "comprovado que o requerente de benefício é portador do vírus HIV, cabe ao julgador verificar as condições pessoais, sociais, econômicas e culturais, de forma a analisar a incapacidade em sentido amplo, em face da elevada estigmatização social da doença" (BRASIL, 2014).

Nos termos do Art. 14 da Lei $n^{\circ} 10.259$ compete à Turma Nacional processar e julgar o incidente de uniformização de interpretação de lei federal em questões de direito material 
fundado em divergência entre decisões de turmas recursais de diferentes regiões ou em face de decisão de uma turma recursal proferida em contrariedade à súmula ou jurisprudência dominante do Superior Tribunal de Justiça.

Importante frisar que o Art. 3 da Lei ${ }^{\circ} 10.259$ diz que compete ao Juizado Especial Federal Cível processar, conciliar e julgar causas de competência da Justiça Federal até o valor de sessenta salários mínimos, bem como executar as suas sentenças. Trata-se de competência absoluta, e por consequência a TNU como responsável pela interpretação da legislação federal e uniformização da jurisprudência dos Juizados Especiais Federais ao editar a súmula 78 contribui para melhor aplicação da norma jurídica.

De acordo com o enunciado supramencionado, nos casos de benefícios previdenciários por incapacidade em que o segurado é portador do vírus HIV o Juiz não está vinculado ao laudo pericial, devendo buscar o exame das especificidades que envolvem o caso, como circunstancias pessoais, culturais, econômicas e sociais, de forma a averiguar se subsiste capacidade, incapacidade parcial ou incapacidade total para as atividades laborativas.

Tal análise abrangente da incapacidade irá conjugar o HIV/AIDS com as situações pessoais, culturais, econômicas e sociais, e buscar uma conclusão razoável do caso no que tange a valoração da incapacidade.

Um entendimento mais abrangente com a conjugação de todos os fatores que pode contribuir direta e indiretamente para a incapacidade do portador da AIDS poderá ser aplicado em virtude da peculiaridade da doença.

Sendo confirmada a inaptidão o segurado terá que se afastar de suas atividades, com a finalidade de se tratar, podendo fazer jus aos benefícios previdenciários por incapacidade, como auxílio-doença e aposentadoria por invalidez. Inclusive, o próprio Decreto 3048/99 aponta depressão no anexo II, Lista B, grupo V, item VII como doença psíquica.

Não se cogita através do emprego do entendimento da TNU conferir aos portadores do HIV a simples e exclusiva concessão de benefícios previdenciários por incapacidade, na verdade a observância das questões sociais, culturais, pessoais e econômicas visa a ofertar e concretizar os valores e princípios constitucionais de modo que o segurado enfermo possa gozar de uma vida digna.

\section{O HIV/AIDS e os benefícios por incapacidade no regime geral de previdência social}


No Brasil, o art. 201, inciso I, da Constituição Federal, garante o direito a Previdência Social. Tal direito social atenderá, nos termos da Lei, a cobertura de eventos de doença e invalidez.

Ao analisar-se tal norma, extrai-se que a previdência social está inserida dentro do Título VIII (Da Ordem Social), Capítulo II (Da Seguridade Social). Os direitos sociais estão no patamar de cláusula pétrea, nos termos do art. 60, parágrafo $4^{\circ}$, inciso IV, vedando a apreciação ou deliberação de qualquer emenda constitucional tendente a aboli-lo.

As regras do Regime Geral de Previdência Social estão previstas na Lei 8.212/91 (Plano de Custeio) e Lei 8.213/91, bem como pelo Decreto 3.048/99 que estabelece o Regulamento da Previdência Social.

Marcelo Leonardo Tavares (2011, p. 28) ensina que:

A previdência no Regime Geral de Previdência Social é conceituada como seguro público, coletivo, compulsório, mediante contribuição e que visa os seguintes riscos sociais: incapacidade, idade avançada, tempo de contribuição, encargos de família, morte e reclusão.

O Regime Geral de Previdência Social (RGPS) é obrigatório para todos os que exercem atividade remunerada, com a exceção dos titulares de cargos públicos efetivos e militares filiados ao Regime Próprio de Previdência Social da União, Estados, Municípios e Distrito Federal.

O RGPS não tem o espoco de simplesmente manter um padrão social dos beneficiários, e sim conceder a cobertura mínima necessária para a manutenção de uma vida digna (AMADO, 2014, p.100).

Assim, a concessão de parcelas previdenciárias aos enfermos se revela como implementação e realização de um direito constitucional, sendo que o plano de prestações do Regime Geral de Previdência Social abarca várias espécies, dentre elas o benefício de aposentadoria por invalidez e auxílio-doença.

\subsection{Da aposentadoria por invalidez}


Em ocorrendo o risco incapacidade a Lei prevê a aposentadoria por invalidez. Tal direito brota do art. 201, inciso I, da Constituição Federal e é previsto pela Lei 8.213/91, art. 42, caput, bem como pelo Decreto 3.048/99, caput, assim definido:

Art. 42. A aposentadoria por invalidez, uma vez cumprida, quando for o caso, a carência exigida, será devida ao segurado que, estando ou não em gozo de auxíliodoença, for considerado incapaz e insusceptível de reabilitação para o exercício de atividade que lhe garanta a subsistência, e ser-lhe-á paga enquanto permanecer nesta condição.

Segundo a doutrina a aposentadoria por invalidez é:

O benefício substituidor dos salários, de pagamento continuado, provisório ou definitivo, pouco reeditável, devido a segurado incapaz para o seu trabalho e insuscetível de reabilitação para o exercício de atividade garantido da subsistência. (MARTINEZ, 2010, p. 847)

A aposentadoria por invalidez embora seja reversível, seu deferimento demanda uma segura convicção da irreversibilidade da incapacidade do segurado, ou seja, que não haja possibilidade plausível do segurado ser reabilitado para outra atividade laborativa (AMADO, 2014, p. 443).

Tal benefício em regra exige carência de 12 (doze) contribuições mensais, ou seja, para o segurado fazer jus a aposentadoria por invalidez deve a partir da filiação contribuir por 12 meses nos termos da Lei 8.213/91, art. 25, inciso I.

Contudo, em se tratando dos portadores da AIDS o Legislador assegurou nos termos do art. 26, II combinado com o art. 151 todos da Lei 8.213/91 que tais segurados podem gozar da aposentadoria por invalidez independente de carência.

Vale relatar que a aposentadoria por invalidez dependerá da verificação da condição de incapacidade definitiva para o labor habitual que exercia o segurado, independentemente do recebimento anterior do benefício previdenciário de auxílio-doença, mediante exame médico-pericial a cargo da Previdência Social, podendo o segurado, às suas expensas, fazer-se acompanhar de médico de sua confiança. Se porventura o segurado não tiver condições de ir ao local da perícia, o perito deverá ir até ele.

Para a obtenção do benefício previdenciário de aposentadoria por invalidez no RGPS não subsiste necessidade de concessão prévia do auxílio-doença, ou seja, a incapacidade total e permanente pode ser constatada já na primeira perícia. Entretanto, é comum o INSS 
conceder primeiramente o benefício de auxílio-doença, e posteriormente, após concluir pela incapacidade total e permanente conceder a jubilação por invalidez.

A concessão da aposentadoria por invalidez estará assegurando direito a vida digna ao portador do HIV após a conjugação e valoração das circunstancias culturais, econômicas e sociais, direito este que constitui a mais preciosa garantia individual.

Colha-se entendimento do Tribunal Regional Federal da Segunda Região (TRF2):

AUXÍLIO-DOENÇA/APOSENTADORIA POR INVALIDEZ. INCAPACIDADE PARCIAL. ASPECTO SOCIAL DA DEMANDA. HIV. TERMO INICIAL. JUROS DE MORA E CORREÇÃO MONETÁRIA. RECURSO DA PARTE AUTORA, DO INSS E REMESSA PROVIDOS EM PARTE. - O laudo pericial conclui que o autor é portador de HIV, gonartrose (doença articular no joelho), dermatite de contatos por irritantes e sinusite crônica, concluindo que está incapacitado para as atividades que exijam esforço físico e que o exponham a substâncias com resina. - O caso em apreço possui aspectos subjetivos e peculiares que não podem ser ignorados pelo Julgador, notadamente a idade do autor (54 anos), o fato de ser pessoa humilde, sempre exercendo a profissão de pedreiro, possuindo saúde debilitada, sem condições de exercer atividades burocráticas ou intelectuais. - Através do CNIS, é possível perceber que o autor, majoritariamente, exerceu suas funções em empresas de construção civil, onde desenvolveu quadro de alergia crônica, estando ainda incapacitado para atividades que exijam esforço físico, tal como a de pedreiro, devido à gonartrose de que é portador. - É pouco crível que tenha condições de ingressar no mercado de trabalho para a função a qual fora reabilitado (operador de computador), considerando a própria competitividade do mercado e a condição de desigualdade criada, seja por conta da doença de que é portador, seja porque exerceu quase sempre a função de pedreiro, o que dificulta o início de uma nova profissão em meio de trabalho totalmente desconhecido e ainda aos seus 54 anos de idade. Inclusive, consta na documentação juntada pelo autor que devido à sinusite crônica de repetição, está com indicação de cirurgia e que, apesar do tratamento do quadro de gonartrose dos joelhos e tendões, não está tendo melhora clínica. E também está apresentando quadro de gastrite persistente e refluxo (fl. 424) - Seguindo a linha do que vem decidindo a Turma Nacional de Jurisprudência, restando comprovado que o requerente de benefício é portador do vírus HIV, cabe ao julgador verificar as condições pessoais, sociais, econômicas e culturais, de forma a analisar a incapacidade em sentido amplo, em face da elevada estigmatização social da doença (Súmula $\mathrm{n}^{\circ}$ 78). Com efeito, nos casos de portadores de HIV, mesmo os assintomáticos, a incapacidade transcende a própria limitação física e repercute na esfera social do requerente, segregando-o, muitas vezes, do mercado de trabalho. De fato, não há como desconsiderar, neste caso específico, o aspecto social da demanda, sendo totalmente inviabilizada a reinserção do autor no mercado de trabalho, tendo sempre em mira o princípio vetor constitucional da dignidade da pessoa humana (artigo 1, III, da CRFB). - Ademais, seria totalmente contraditório conceder o auxílio-doença e a reabilitação profissional 1 do autor e o seu retorno ao mercado de trabalho, conquanto tenha restado comprovada a sua impossibilidade fática, tanto que, após a reabilitação do autor, ele foi alocado para outra profissão, onde permaneceu em contato com as substâncias que lhe causam alergia. - Diante dos esclarecimentos do perito judicial e do conjunto probatório constante nos autos e obedecendo ao princípio do livre convencimento motivado, entendo que deve ser restabelecido o auxílio-doença da parte autora desde a data da sua cessação, devendo, contudo, haver a conversão em aposentadoria por invalidez a partir da data do presente acórdão, já que este Relator, em seu decisum, considerou primordialmente o aspecto social da demanda. - No tocante ao pedido de dano 
moral, entendo que o tão-só fato de um benefício previdenciário ter sido cessado não caracteriza de plano a ocorrência de situações humilhantes, vexatórias ou que causem algum distúrbio psíquico mais sério a ponto de gerar o malsinado dano moral. Ao contrário, aproxima-se mais da situação descrita pela doutrina como parte dos meros dissabores do cotidiano, principalmente no dia-a-dia forense. Até mesmo porque, ao que consta nos autos, o benefício foi cessado por conta da reabilitação do autor para outra função e devido à perícia da Autarquia não ter constatado a permanência da incapacidade para esta nova função, sendo certo que o INSS, como órgão da Administração Pública deve agir dentro da legalidade, ao contrário do Judiciário que, além da legalidade estrita, pode fazer considerações a respeito de aspectos pessoais, sociais,econômicos e culturais para decidir uma lide. - A fixação dos juros de mora e da correção monetária deve observar o Enunciado $\mathrm{n}^{\circ} 56$ da Súmula desta Eg. Corte, bem como o entendimento firmado pelo Plenário do eg. Supremo Tribunal Federal, no julgamento conjunto das ADI's n's 4.357, 4.327, 4.400 e 4.425 , que declarou a inconstitucionalidade parcial, por arrastamento, $1^{\circ}$-F da Lei $\mathrm{n}^{\circ}$ 9.494/97, introduzido pelo art. $5^{\circ}$ da Lei 11.960/2009, assim como a jurisprudência do Superior Tribunal de Justiça firmada em sede de recurso repetitivo (1 ${ }^{\text {a }}$ Seção, REsp 1270439, Rel. Min. Castro Meira, DJ de 02/08/2013), de modo que, a partir da vigência da Lei 11.960/09, a correção monetária deve ser feita pela aplicação do índice que melhor reflete a inflação acumulada do período e os juros de mora devem ser os aplicáveis às cadernetas de poupança. - Recursos e remessa providos em parte. (BRASIL, 2017) grifou-se

O TRF2 no acórdão supramencionado aplicou a súmula 78 da TNU para deferir ao segurado o benefício de aposentadoria por invalidez. Observou-se no caso concreto o laudo pericial que concluiu que o autor era portador de HIV, entre outras enfermidades, bem como os aspectos subjetivos e peculiares como a idade (54 anos), o fato de ser pessoa humilde, exercício da profissão de pedreiro, saúde debilitada, sem condições de exercer atividades burocráticas ou intelectuais e as poucas condições do segurado ingressar no mercado de trabalho.

Na decisão do TRF2 o relator fundamenta que nos casos de portadores de HIV, mesmo os assintomáticos, a incapacidade transcende a própria limitação física e repercute na esfera social do requerente, segregando-o, muitas vezes, do mercado de trabalho.

Uma solução que pode ser empregada no caso concreto, após um estudo aprofundado, é deferir a aposentadoria por invalidez ao segurado com AIDS, pois nesse estágio observa-se um grau mais acentuado da imunodepressão provocada pelo HIV, como surgimento de tumores, infecções, entre outros, sempre com a observância da Súmula 78 da TNU.

Importante salientar que a concessão do benefício previdenciário de aposentadoria invalidez no RGPS com a verificação e observância das condições pessoais, sociais, econômicas e culturais, de forma a analisar a incapacidade em sentido amplo, em face da elevada estigmatização social do HIV/AIDS não constitui simples aplicação da Lei 8.213/91, 
como também a observância e aplicação no caso concreto do princípio constitucional da dignidade da pessoa humana previsto no artigo $1^{\circ}$, III, da Constituição Federal, bem como do princípio previdenciário da solidariedade, que segundo a doutrina tem o seguinte significado:

\begin{abstract}
Cooperação da maioria em favor da minoria, em certos casos, da totalidade em direção à individualidade. Dinâmica a sociedade, subsiste constante alteração dessas parcelas e, assim, num dado momento, todos contribuem e, noutro, muitos se beneficiam da participação da coletividade. Nessa ideia simples, cada um também se apropria de seu aporte. Financeiramente, o valor não utilizado por uns é canalizado para outros. Significa a cotização de certas pessoas, com capacidade contributiva, em favor dos despossuídos. Socialmente considerada, é ajuda marcadamente anônima, traduzindo mútuo auxílio, mesmo obrigatório, dos indivíduos. (MARTINEZ, 2010, p. 121)
\end{abstract}

Segundo Sergio Pinto Martins (2007, p. 51) a solidariedade por ser entendida como um postulado fundamental da Seguridade Social, sendo uma característica humana, uma ajuda aos desfavorecidos.

O portador do HIV/AIDS que postula a concessão do benefício de aposentadoria por invalidez deve ser tratado com amor, com compaixão/solidariedade, ou seja, a solidariedade pode ser empregada como princípio na verificação do caso em que o portador do HIV/AIDS postula a aposentadoria por invalidez ou auxílio-doença.

Cabe mencionar que a alíquota da renda mensal da aposentadoria será de $100 \%$ do salário de benefício nos termos do art. 44 da Lei 8.213/91, sendo que de acordo com o art. 45 da mesma Lei o valor da jubilação por invalidez pode ser acrescido de $25 \%$ quando comprovado que o beneficiário da previdência social necessita da assistência permanente de outra pessoa.

Segundo IBRAHIM (2009, p. 606) o aposentado por invalidez que se julgar apto a retornar ao trabalho deverá requerer avaliação médico-pericial. Assim, após a realização da perícia o segurado poderá trabalhar, bem como obter redução gradativa em seu benefício de aposentadoria por invalidez, sendo estes pagamentos denominados mensalidades de recuperação.

As mensalidades de recuperação estão previstas no art. 47 da Lei 8.213, sendo que quando a recuperação ocorrer dentro de 5 (cinco) anos, contados da data do início da aposentadoria por invalidez ou do auxílio-doença que a antecedeu sem interrupção, o benefício cessará: 
a) de imediato, para o segurado empregado que tiver direito a retornar à função que desempenhava na empresa quando se aposentou, na forma da legislação trabalhista, valendo como documento, para tal fim, o certificado de capacidade fornecido pela Previdência Social; $\mathrm{ou}$

b) após tantos meses quantos forem os anos de duração do auxílio-doença ou da aposentadoria por invalidez, para os demais segurados.

Em se tratando de recuperação parcial, ou que venha ocorrer após o período do inciso I, ou ainda quando o segurado for declarado apto para o exercício de trabalho diverso do qual habitualmente exercia, a aposentadoria será mantida, sem prejuízo da volta à atividade:

a) no seu valor integral, durante 6 (seis) meses contados da data em que for verificada a recuperação da capacidade;

b) com redução de 50\% (cinquenta por cento), no período seguinte de 6 (seis) meses;

c) com redução de $75 \%$ (setenta e cinco por cento), também por igual período de 6 (seis) meses, ao término do qual cessará definitivamente.

\subsection{Do auxílio-doença}

Assim como o benefício de aposentadoria por invalidez, o benefício previdenciário de auxílio-doença tem previsão constitucional no art. 201, inciso I, estando inserido dentro do Título VIII (Da Ordem Social), Capítulo II (Da Seguridade Social), se revelando cláusula pétrea, nos termos do art. 60, parágrafo $4^{\circ}$, inciso IV da CRFB.

Tal prestação é prevista pela Lei 8.213/91 nos artigos 59 a 63 e Decreto 3.048/99 nos artigos 71 a 80, sendo devido ao segurado que, havendo cumprido, quando for o caso, a carência exigida, ficar incapacitado para o seu trabalho ou para a sua atividade habitual por mais de 15 (quinze) dias consecutivos.

O objetivo de tal benefício é assegurar uma prestação mensal de $91 \%$ do salário de benefício ao segurado inapto ao trabalho, sendo que tal incapacidade poderia ser de várias formas, quais sejam, doenças típicas, de natureza moral, social, familiar etc.

Uma das características do auxílio-doença é o seu caráter provisório, pois será devido enquanto perdurar a enfermidade. A aposentadoria por invalidez, como já mencionada, exige uma aferição de irreversibilidade da incapacidade laboral. 
O auxílio-doença cessa pela recuperação da capacidade para o trabalho, pela transformação em aposentadoria por invalidez ou pela reabilitação profissional (quando seja dado como habilitado para o exercício de nova profissão).

Tal benefício em regra exige carência de 12 (doze) contribuições mensais, ou seja, para o segurado fazer jus ao auxílio-doença deve a partir da filiação contribuir por 12 meses nos termos da Lei 8.213/91, art. 25, inciso I.

Contudo, como já mencionado em se tratando dos portadores da AIDS o Legislador assegurou no art. 151 da Lei 8.213/91 que tais segurados podem gozar do benefício de auxílio-doença independente de carência.

Cumpre mencionar que o deferimento do benefício de auxílio-doença dependerá da verificação da condição de incapacidade mediante exame médico-pericial a cargo da Previdência Social, podendo o segurado, às suas expensas, fazer-se acompanhar de médico de sua confiança. O procedimento administrativo e judicial é o mesmo aplicado à aposentadoria por invalidez.

Frederico Amado (2014, p. 521) entende que é possível a concessão do benefício de auxílio-doença em duas hipóteses:

a) Incapacidade parcial ou total para o trabalho habitual por mais de 15 dias consecutivos, sendo plenamente possível a recuperação para a mesma atividade;

b) Incapacidade permanente parcial ou total do segurado para o trabalho habitual por mais de 15 dias consecutivos, não sendo possível a recuperação para a atividade de trabalho habitual, porém sendo viável reabilitação profissional para outra atividade.

Nos casos de requerimentos de auxílio-doença em que os requerentes são portadores do HIV/AIDS necessária à aplicação da Súmula 78 da TNU com a verificação e observância das condições pessoais, sociais, econômicas e culturais, de forma a analisar a incapacidade em sentido amplo, em face da elevada estigmatização social do HIV/AIDS.

Tal entendimento pode ser empregado ao portador assintomático ou soropositivo. Como já mencionado o portador assintomático ou soropositivo é a pessoa que, tendo tido contado com o vírus e possuindo anticorpos detectáveis em seu sangue, não apresenta sintomas, podendo vir a desenvolver a doença ou não.

Também o auxílio-doença poderá ser deferido ao segurado que se encontra com Complexo Relacionado à AIDS (ARC). Em tal etapa a pessoa soropositiva apresenta sintomas 
e sinais inespecíficos de intensidade variável, além de processos de menor gravidade, podendo exteriorizar fadiga, diarreia crônicas, emagrecimento, febre etc.

Em tais situações o segurado deverá ser submetido aos procedimentos periciais de tempo em tempo, e de acordo com a Lei 8.213/91, art. 60, $\S 8^{\circ}$, sempre que possível, o ato de concessão ou de reativação de auxílio-doença, judicial ou administrativo, deverá fixar o prazo estimado para a duração do benefício.

Caso não seja fixado prazo de que trata o $\S 8^{\circ}$ do artigo supracitado, o benefício de auxílio-doença cessará após o prazo de cento e vinte dias, contado da data de concessão ou de reativação do auxílio-doença, devendo o segurado se quiser requerer a sua prorrogação perante a autarquia previdenciária.

\section{Conclusão}

Como demonstrado a Síndrome da Imunodeficiência Adquirida (AIDS) é uma doença viral e caracteriza-se por diversas manifestações clínicas provocadas pela presença do Vírus da Imunodeficiência Humana (HIV).

Mostrou-se que quando o vírus HIV foi identificado não havia tratamentos disponíveis e seu desfecho era rápido, com altas taxas de mortalidade, e que com o surgimento da terapia antirretroviral tripla de alta potencia (TARV), conhecido como "coquetel" ocorreu à redução da mortalidade, diminuição na frequência e duração de internações, bem como o aumento da sobrevida.

O direito à saúde junto com a assistência social e previdência social formam a seguridade social, e constitui um direito fundamental pois decorre de garantir um ampla atendimento e suprir necessidades vitais que são semelhantes para todos os seres humanos.

Porém, mesmo diante do avanço científico verificou-se que o HIV e a AIDS geram não somente a incapacidade física, como também problemas sociais, tais como o estigma, preconceito, reações ao tratamento etc.

$\mathrm{O}$ atendimento, tratamento e comportamento do Estado e da sociedade deve pautar-se em respeitar os portadores do HIV/AIDS de modo a não promover a segregação e discriminação. 
Todo portador do HIV/AIDS é um ser humano e como tal tem direito a uma vida digna e plena em todos os aspectos da vida social, em especial à continuação de sua vida civil, profissional, sexual e afetiva.

Compulsando a súmula $n^{\circ} 78$ da Turma Nacional de Uniformização (TNU) dos Juizados Especiais Federais constatou-se que as condições pessoais, sociais, econômicas e culturais, podem ser ponderadas no caso concreto para a verificação da incapacidade laborativa.

De acordo com a jurisprudência trazida à incapacidade laboral numa primeira análise pode ser demonstrada e visualizada de forma objetiva, em especial no que tange a presença do HIV. Porém, os aspectos subjetivos e peculiares devem ser valorados.

Trouxe-se consideração no tocante a Previdência Social Brasileira através da Constituição Federal e Legislação infraconstitucional (Lei 8.213/91 e Decreto 3.048/99), demonstrando que o RGPS não tem por simples finalidade manter um padrão social dos beneficiários, e sim conceder a cobertura mínima necessária para a manutenção de uma vida digna.

Para corporificar e materializar os direitos constitucionais o Regime Geral de Previdência Social prevê a concessão dos benefícios de aposentadoria por invalidez e auxíliodoença.

A aposentadoria por invalidez como benefício substituidor da remuneração é devida ao segurado incapaz para o seu trabalho e insuscetível de reabilitação para o exercício de atividade garantido da subsistência, sendo possível a concessão da aposentadoria por invalidez ao segurado com AIDS, pois nesse estágio observa-se um grau mais acentuado da imunodepressão provocada pelo HIV, como surgimento de tumores, infecções, entre outros. Vale ressaltar que deve-se valorar as condições pessoais, sociais, econômicas e culturais do segurado, nos termos da súmula 78 da TNU.

O benefício de auxílio-doença tem como característica o seu caráter provisório, pois será devido enquanto perdurar a enfermidade, e conforme o presente estudo poderá ser concedido ao portador assintomático ou soropositivo, bem como ao segurado que se encontra com Complexo Relacionado à AIDS (ARC), com a utilização do entendimento exposto na súmula 78 da TNU.

\section{Referências}


AFFELDT, Ângela Beatriz; SILVEIRA, Mariângela Freitas da; BARCELOS, Raquel Siqueira. Perfil de pessoas idosas vivendo com HIV/aids em Pelotas, sul do Brasil, 1998 a 2013. Epidemiol. Serv. Saúde, Brasília, v. 24, n. 1, p. 79-86, Mar. 2015.

ALENCAR, Tatiana Meireles Dantas de; NEMES, Maria Ines Batistella; VELLOSO, Marco Aurélio. Transformações da "aids aguda" para "aids crônica": percepção corporal e intervenções cirúrgicas entre pessoas vivendo com HIV e aids. Ciência \& Saúde Coletiva, v.13, n.6, p.1841-1849, $2008 . \quad$ Disponível <http://www.producao.usp.br/bitstream/handle/BDPI/9375/art_ALENCAR_Transformacoes_ da_e34aids_agudae34_para_a_e34aids_2008.pdf?sequence=1>. Acesso em 04 ago. 2017.

AMADO, Frederico. Curso de direito e processo previdenciário. 5. ed. Salvador: JusPODIVM, 2014.

BRASIL. Casa Civil. Constituição da República Federativa do Brasil de 1988. Brasília, 5 de outubro de $1988 . \quad$ Disponível em: <http://www.planalto.gov.br/ccivil_03/constituicao/constituicao.htm>. Acesso em: 01 ago. 2017.

Casa Civil. Lei no 8080, de 19 de setembro de 1990. Dispõe sobre as condições para a promoção, proteção e recuperação da saúde, a organização e o funcionamento dos serviços correspondentes e dá outras providências. Disponível em: <http://www.planalto.gov.br/ccivil_03/leis/L8080.htm>. Acesso em: 09 ago. 2017.

Casa Civil. Lei no 8213, de 24 de julho de 1991. Dispõe sobre os Planos de Benefícios da Previdência Social e dá outras providências. Disponível em: <http://www.planalto.gov.br/ccivil_03/leis/L8213cons.htm>. Acesso em: 01 ago. 2017.

Casa Civil. Lei ${ }^{\circ}$ 10.259, de 12 de julho de 2001. Dispõe sobre a instituição dos Juizados Especiais Cíveis e Criminais no âmbito da Justiça Federal. Disponível em: < http://www.planalto.gov.br/ccivil_03/leis/LEIS_2001/L10259.htm>. Acesso em: 04 ago. 2017.

Ministério da Saúde. Secretaria de Vigilância em Saúde. Departamento de Vigilância epidemiológica. Doenças infecciosas e parasitárias: guia de bolso. 8. ed. Ver. Brasília: Ministério da Saúde. 2010.

_. Ministério da Saúde. Portal Saúde. Direitos fundamentais dos portadores do vírus hiv. Brasília: Ministério da Saúde. 2014. Disponível em:< http://portalsaude.saude.gov.br/index.php/links-de-interesse/286-aids/12306-direitosfundamentais-dos-portadores-do-virus-hiv>. Acesso em: 08 ago. 2017.

Previdência Social. Manual de perícia médica da Previdência Social. Disponível em:<http://www.consultaesic.cgu.gov.br/busca/dados/Lists/Pedido/Attachments/438067/RES POSTA_RECURSO_2_manualpericiamedica\%20(1).pdf >. Acesso em: 10 ago. 2017. 
- Turma Nacional de Uniformização dos Juizados Especiais Federais. SUM-78. Comprovado que o requerente de benefício é portador do vírus HIV, cabe ao julgador verificar as condições pessoais, sociais, econômicas e culturais, de forma a analisar a incapacidade em sentido amplo, em face da elevada estigmatização social da doença. Brasília, 11 de setembro de 2014. Disponível em: <https://www2.jf.jus.br/phpdoc/virtus/>. Acesso em: 25 abr. 2017.

. Tribunal Regional Federal (2. Região). Apelação Cível nº 00069513020124025001. Relator: Desembargador Messod Azulay Neto. Rio de Janeiro, 07 de julho de 2015. Disponível em: <https://www2.jf.jus.br/juris/unificada/Resposta>. Acesso em: 27 de jul. 2017.

COURA, José Rodrigues. Síntese das doenças infecciosas e parasitárias. Rio de Janeiro: Guanabara Koogan, 2008.

ESTADÃO. Aids avança no Brasil entre 2010 e 2015, afirma UNAids. Disponível $\mathrm{em}:<$ http://saude.estadao.com.br/noticias/geral,aids-avanca-no-brasil-dizunaids, $10000062378>$. Acesso em: 04 ago. 2017.

IBRAHIM, Fábio Zambitte. Curso de Direito Previdenciário. 14. ed. Rio de Janeiro: Impetus, 2009.

MARTINEZ, Wladimir Novaes. Curso de direito previdenciário. 3. ed. São Paulo: LTr, 2010.

MARTINS, Sergio Pinto. Direito da Seguridade Social. 24. ed. São Paulo: Atlas, 2007.

SARLET, Ingo Wolfgang. Dignidade da pessoa humana e direitos fundamentais na Constituição Federal de 1988. 2. ed. Porto Alegre: Livraria do Advogado, 2002.

SERRANO, Pablo Jiménez. Teoria do direito: contribuição ao pensamento jurídico contemporâneo. Rio de Janeiro: Jurismestre, 2017.

SILVA, José Afonso da. Curso de direito constitucional positivo. 39. ed. São Paulo: Malheiros, 2016.

TAVARES, Marcelo Leonardo. Direito Previdenciário. 13. ed. Rio de Janeiro: Impetus, 2011.

TOLEDO JÚNIOR, Antonio Carlos de Castro. Pragas e Epidemias: Histórias de doenças infecciosas. Belo Horizonte: Folium, 2006.

UNAIDS. Estigma e discriminação. Disponível em:<http://unaids.org.br/estigma-ediscriminacao/>. Acesso em: 08 ago. 2017. 